\title{
Marcas da guerra em terra distante: relatos de japoneses em São Paulo
}

\author{
Zeila de Brito Fabri Demartini*
}

A IMIGRAÇÃo JAPONESA PARA O BRASIL, especialmente para o estado de São Paulo, local em que se concentraram os imigrantes, ainda não completou um século desde seu início. Mas as vivências neste novo contexto registram momentos traumáticos que marcaram a história do grupo e, que, de modo explícito ou através do silêncio, são evidenciados quando os próprios imigrantes ou seus descendentes contam suas próprias histórias. Neste artigo trataremos de relatos sobre um período do qual os nipo-brasileiros não gostam de falar ou sobre o qual falam muito pouco: o sofrido período da Segunda Guerra Mundial e o traumático pós-guerra em São Paulo, também chamado de "período do vale tenebroso", "período da escravidão", "espaço branco na história da imigração nipônica”. (Uma epopéia, 1992, p. 378)

Lembramos aqui que a primeira etapa da imigração japonesa para o Brasil, iniciada em 1908, encerra-se em 13 de agosto de 1941. Foi neste período de 33 anos que o grupo japonês, composto nesta última data por 190 mil pessoas, foi se estruturando no contexto paulista (e paulistano), nele estabelecendo novas relações sociais e configurando novas vivências (Demartini et al., 1997). A imigração só foi retomada a partir de 1952, quando começaram a chegar as famílias japonesas que procuravam escapar das durezas do pós-guerra no Japão; esta nova imigração tem uma entrada anual grande até 1979, quando começou a

* Centro de Estudos Rurais e Urbanos - Universidade de São Paulo (CERU-USP); Universidade Metodista de São Paulo. 
entrar em declínio; observou-se então um novo movimento, que se intensificou nos anos 1980, na história deste grupo japonês: a imigração para o Japão, na condição de "dekassegui". Atualmente existem mais de 200.000 brasileiros morando no Japão, nesta condição.

Pesquisa realizada pelo Centro de Estudos Nipo-Brasileiro indicava que o Estado de São Paulo em 1977 concentrava a população de origem japonesa, com um total de 727.605 pessoas (123.165 eram de nacionalidade japonesa e os demais 604.440 eram nisseis naturalizados, nisseis e sanseis). Deste total, 326.000 residiam na cidade de São Paulo e mais de 170.000 na Grande São Paulo (excluindo a cidade de São Paulo) totalizando, portanto, nesta região delimitada, 64,7\% do conjunto da população Nikkei residente no Brasil - no Brasil, esta população totalizava 765.710 pessoas. (Uma epopéia, 1992, p. 425) Assim, tratar das especificidades da vivência deste grupo na região metropolitana significa refletir sobre as questões pertinentes a uma grande parcela das pessoas de origem japonesa no Brasil.

Analisamos aqui os relatos orais de pessoas que vivenciaram o período da Segunda Guerra Mundial e do Pós-Guerra em São Paulo, obtidos durante pesquisas por nós realizadas em que entrevistamos diferentes gerações de famílias japonesas que chegaram a São Paulo nas décadas de 1920 e 1930, assim como famílias que chegaram no pósguerra, além de algumas pessoas que conviveram intensamente com as mesmas neste período.

$\mathrm{Na}$ primeira pesquisa foram 16 entrevistados do grupo japonês, sendo sete mulheres e nove homens, que contaram sobre as vivências de suas famílias; como só quatro pertenciam à mesma família, as informações referiram-se a um conjunto de 14 famílias. Alguns deles (três) falaram também sobre a história do grupo, em colônia da periferia de São Paulo, como representantes de mais de cem famílias. ${ }^{1} \mathrm{Na}$ segunda pesquisa, trabalhamos com as segunda e terceira gerações dessas famílias, assim como entrevistamos outras três famílias que vieram no pós-guerra. ${ }^{2}$

1 Projeto Integrado de Pesquisa Família em São Paulo: as especificidades estruturais e conjunturais da mediação indivíduo e sociedade, sub-projeto 4: Vida familiar de diferentes grupos étnicos em São Paulo: os japoneses.

2 Projeto Integrado de Pesquisa Família em São Paulo: trajetórias no pós-guerra (1950-1980), sub-projeto 4: Família, imigração e cultura (1950-1980): japoneses. 
Nesses estudos, interessaram-nos as representações dos entrevistados sobre suas vivências em São Paulo, especialmente temas amplos relacionados com a mobilidade sócio-espacial das famílias, os projetos individuais e coletivos de ascensão sócio-econômica, o processo de escolarização das gerações mais jovens, a questão da língua, a vivência cultural nas diferentes gerações de cada família, as histórias de família e, envolvendo todas essas, principalmente a questão da identidade.

Trabalhamos nestas pesquisas com o que denominamos histórias de vida resumidas (Demartini, 1988); assim, tentando aprender os relatos das pessoas sobre o conjunto de suas vidas, aprofundamos as dimensões que mais interessavam à investigação, a partir dos próprios relatos construídos pelo entrevistado. $\mathrm{O}$ relato oral foi coletado num processo de interação entrevistado/entrevistador em que nos colocamos numa posição de escuta atenta, cuidadosa, paciente, de modo a estabelecer a cumplicidade necessária para que o entrevistado se colocasse em situação de querer falar. Deste modo, enquanto pesquisadores, tentamos aprender a escutar (inclusive o relato oculto) para podermos encontrar o momento certo de colocar as questões que nos interessava investigar. Como se trabalhou com a pluralidade de sujeitos implicando, portanto, em maior número de entrevistados, tornou-se difícil optar pela realização de histórias de vida na concepção que lhe é dada por Maria Isaura Pereira de Queiroz (1991). Tentamos adotar aqui a postura, muito bem observada por Carl F. Schorske, ao comentar as entrevistas apresentadas por Bourdieu em La misère du monde:

"Em A miséria do mundo, Bordieu faz apelos a modos literários e pré-científicos de compreensão sociológica, assim como a retórica para a comunicar. A substância empírica de $A$ miséria é feita de histórias delicadas e tocantes, contadas pelas pessoas elas mesmas prisioneiras, fala-se de todo e cada um do tecido social. Esses pedaços de vida humana, muito humana, fazem mais que oferecer à análise científica as ocasiões de se exercer. Elas revivem a sensibilidade moral, a empatia que a sociologia moderna havia expulsado adotando a fria abstração da ciência. Em A miséria os objetivos científicos do sociólogo são colocados face aos comentários sobre os textos autobiográficos passando pelo diálogo que, sem poder para formular ou verificar os princípios estruturais, fazem 
prova de um certo poder de revelação. " (Schorske, 1995, p. 701)

Nossa opção foi pela diversidade de sujeitos. Entrevistamos pessoas que cresceram em famílias que viviam em espaços mais fechados, chamados de "colônia", geralmente na periferia da cidade; outros que residiam em bairros centrais ou esparsos pela cidade, assim como os que residiram no interior do estado, vindo depois para São Paulo. Eram, portanto, pessoas com vivências diferenciadas, que nos permitiram apreender representações diversas sobre os mesmos acontecimentos durante o processo de relatar suas histórias de vida.

Se o "ser imigrante", para usar a expressão de Sayad (1991), traz homogeneidades dadas pelo processo de saída e chegada e pela ilusão da "provisoriedade da condição" em que vivem, por outro lado parece-nos que os contextos em que se inserem trazem elementos diferenciadores; sem dúvida, estudar a inserção das famílias de origem japonesa no contexto paulistano tornou-se fundamental para verificar as diferenças (com relação à inserção em contextos outros) que se estabeleceram, pelos conflitos e problemas que a convivência intensa e obrigatória com pessoas de outras várias origens colocaram. Já chamamos a atenção em outros estudos para a complexidade das relações que se estabeleceram na sociedade paulista e paulistana durante o século XX, em que passaram a conviver pessoas recém-chegadas de vários países da Europa e do Japão com as "tradicionais" famílias nacionais constituídas por brancos e negros, estes, em sua maioria, recém-saídos da escravidão (Demartini, 1989). Se pensarmos nas colocações de José de Souza Martins (1993) sobre "a chegada do estranho" e as implicações desta situação para os que chegavam e os que já estavam há mais tempo em um espaço dado, podemos pensar nos vários "estranhos" e "estranhamentos" ocorridos entre os brancos nacionais, os negros, os imigrantes europeus e os imigrantes orientais. Poder-se-ia até pensar que todos se tratavam de alguma maneira como "estranhos". Havia ainda os migrantes nacionais, que para cá já se dirigiam em grande número.

Desta forma, consideramos fundamental levar em conta em nossas pesquisas a diversidade e heterogeneidade presentes na sociedade paulista e paulistana, incorporando as considerações de Gilberto Velho sobre o trabalho do pesquisador que lida com a cultura de grupos em sociedade tão complexa: 
"Interessa, sobretudo, a partir dessas colocações preliminares, perguntar o que pode mudar, o que pode ser considerado novo em uma sociedade complexa e heterogênea como a brasileira. A avaliação do que seja consensual e/ou dominante e o que representa comportamento ou valores minoritários e desviantes é etapa difícil, porém fundamental, de discussão. Sem desprezar o valor do senso comum, é importante que o cientista social [...] esteja atento para que seu trabalho não seja simplesmente a confirmação de mitos. O caráter crítico de nosso trabalho passa, entre outras coisas, pelo risco de desagradar e provocar reações preconceituosas dos defensores de dogmas e verdades inaliáveis, como, por exemplo, a unidade da cultura nacional, sua harmonia, integração etc. O fato é que pesquisas que têm sido feitas sobre assuntos e temas, os mais variados como religião, família, sexualidade, entre outros, apontam para a existência de representações e vivências muito diferenciadas dentro de nossa sociedade." (Velho, 1989, p. 52; grifo nosso)

Se Seyferth $(2000,2002)$ dá pistas para pensar na construção e existência de identidades híbridas, como a identidade nipo-brasileira, as reflexões de Gilberto Velho, assim como as diferentes entrevistas que fomos realizando, nos levaram a supor que não há um padrão único para a constituição destas identidades híbridas, nem sobre as representações e vivências neste processo. Considerando São Paulo como o contexto em que viveram as pessoas entrevistadas, isto é, como um campo relacional em que estas pessoas estavam inseridas em determinadas posições, assumindo determinadas ações, apresentando determinadas estratégias, pensamos no "campo de possibilidades" complexo (Velho, 1989) que se apresentou para os vários nipo-brasileiros ao longo deste século.

Dessa forma, partindo já desta perspectiva metodológica, algumas questões foram surgindo ao longo do estudo, especialmente a partir das leituras e re-leituras das entrevistas realizadas com os imigrantes e seus descendentes: em que medida se aproximavam ou não nos relatos dos entrevistados as representações dos que tiveram vivências muito diferenciadas em São Paulo? Os relatos sobre as vivências durante o período da Segunda Guerra Mundial se aproximavam daqueles sobre 
as vivências antes e após a guerra (período da Shindo Renmei)? Até que ponto as entrevistas realizadas sob a forma de histórias de vida resumidas permitiam entrever e discutir algumas questões sobre relatos de situações traumáticas?

Em primeiro lugar, é preciso retomar a especificidade dos relatos obtidos junto a este grupo, em trabalho que representou desafios aos pesquisadores. Enfrentamos algumas dificuldades na realização das entrevistas, o que não havia ocorrido em outros estudos realizados junto a populações nacionais urbanas e rurais, ou a determinados setores dessas, como os professores. Assim, fomos percebendo diferentes tipos de resistências à concessão da própria entrevista. Por terem sido muito controlados, perseguidos e até punidos durante o período da Segunda Guerra Mundial, relembrar o passado implicava para muitos deles em ter presente os difíceis momentos vividos, criando consciente (ou inconscientemente) resistências à realização das entrevistas. Este fato nunca foi explicitado, mas percebido e sentido pelos pesquisadores em várias situações. Uma das estratégias por nós utilizadas, que efetivamente permitiram quebrar a "desconfiança" e conseguir estabelecer as conversas, foi a apresentação às pessoas dos trabalhos por nós anteriormente elaborados e a história das instituições de pesquisa envolvidas (CERU e USP) - parecia haver por parte deles um reconhecimento de que nosso trabalho era honesto e confiável, isto é, não havia perigo em falar.

Mas não foram só as marcas da guerra que estiveram presentes, antes e, durante as entrevistas; outros elementos também se fizeram sentir. Embora residindo no Brasil há muitos anos ou aqui tendo nascido, estes imigrantes têm a cultura japonesa muito presente, manifestando-se fortemente neste processo de entrevista: os japoneses, como fruto de um traço de sua cultura de origem, com algumas exceções, não gostam de falar sobre suas próprias vidas, sobre seus projetos, suas frustrações, suas idéias; cabe aos outros perceberem seus problemas e ajudá-los, mesmo quando as situações são as mais difíceis. Demandar deles, especialmente dos mais velhos, que se "abram", falando de suas vidas, é trabalho difícil, pois implica, para eles, num reposicionamento com relação à sua maneira de ser e pensar (re-pensar sobre si e seu grupo). Outro aspecto também freqüente entre os japoneses, e usado por muitos deles como "desculpa” para não serem entrevistados, era a alegação de 
que não sabiam falar o português direito; este ponto aparece também durante as entrevistas, manifestando-se muitos deles envergonhados pela maneira como falavam.

Nesse processo de construção das histórias de vida entre entrevistados/entrevistadores não pertencentes às mesmas etnias, verificamos que houve dificuldades, mas também aspectos positivos relevantes. Os pesquisadores, muitas vezes por não vivenciarem os códigos culturais de cada grupo, não têm medo de tocar nos espaços e temas tabus, conflitos, privacidade. Enquanto pesquisadores de origem "brasileira", desde que aceitos pelo grupo, pudemos conseguir bons resultados porque nos apresentamos como mais curiosos e com menor autocensura ao formular questões, apresentando ângulos novos para discutir velhas questões. Desta forma, permitimos também acrescentar novas variáveis para a história do grupo, história que só o olhar "oriental" não tinha conseguido dar conta muitas vezes.

Para refletir sobre as questões que colocamos acima, também levamos em conta que as transformações ocorridas com relação ao Japão, no contexto internacional, e com o Brasil, implicaram em mudanças significativas nas vivências das famílias entrevistadas ao longo do século, evidenciando diferentes trajetórias familiares e diferentes estratégias desenvolvidas, isto é, reorientações de seus projetos e práticas no complexo campo de possibilidades delineado em São Paulo.

Assim, salientamos algumas especificidades deste grupo e das famílias entrevistadas em São Paulo no período considerado (especialmente meados de 1930 a meados de 1950). No plano econômico, muitas famílias entrevistadas já haviam conseguido superar antes da Segunda Guerra Mundial as dificuldades financeiras dos primeiros anos, encontrando-se em processo de ascensão econômica e com boa inserção no mercado de trabalho, como produtores (proprietários ou arrendatários), empresários, comerciantes ou como trabalhadores no setor de serviços e na indústria, acompanhando o processo de escolarização crescente observado com relação aos filhos. Mas, para muitas famílias japonesas, incluindo grande parte das pessoas entrevistadas da primeira geração, ainda estava presente nesta época o desejo de retorno, que havia alimentado a própria vinda para o Brasil (Demartini, 1997). Os dados indicam que foram relativamente poucos os que retornaram, mas o desejo de retorno, que sempre existiu e foi ao longo de décadas 
manipulado pelo governo japonês, com o intuito de os manter como "seus" súditos, encontrou neste período um reforço dado pelas circunstâncias políticas.

Viviam no Brasil, enquanto grupo, a pressão da política da nacionalização levada a cabo pelo governo Vargas, o que reforçava o desejo de retorno ao Japão para uma grande maioria (Uma epopéia, 1992, p. 247-378). A grande aspiração era a re-emigração, expressa pelos imigrantes em vários artigos publicados e confirmada por muitos entrevistados da primeira geração.

O grupo japonês nunca foi um grupo bem visto pela sociedade brasileira, especialmente pelos eugenistas e políticos preocupados com o branqueamento da população: não era desejável acrescentar ao povo já "tão misturado" pela presença de negros e índios, também a raça amarela. O japonês só entrou como imigrante porque era considerado um povo agrícola muito trabalhador e, as fazendas naquele período, ainda demandavam mão-de-obra "competente". Mas desde a Primeira Guerra Mundial, o estado de São Paulo, para onde vieram grandes levas de imigrantes, implantou políticas nacionalistas que visavam controlálos e evitar que constituíssem os considerados "perigosos enquistamentos étnicos". O controle sobre as escolas japonesas já era evidente desde então, especialmente porque em torno delas giravam grande parte das atividades dos imigrantes em São Paulo, geralmente constituídos como comunidade socialmente organizada: "as colônias japonesas". (Maeyama, 1972; Hastings, 1969)

Segundo Maeyama (1972), como a Monarquia era o símbolo maior do niponismo antes da Segunda Guerra, o culto ao imperador era o tema central nas atividades culturais do grupo, e também veio substituir o tradicional culto aos ancestrais dentro da comunidade nipo-brasileira, passando a funcionar como referência fundamental para a identificação cultural do grupo.

Devemos levar em consideração a enorme influência do fascismo vigente naquela época. Segundo Maeyama (Idem), muitos dos imigrantes que vieram entre 1926 e 1936 haviam sido fortemente doutrinados com a ideologia teocrática desenvolvida pelo Estado japonês cuja idéia central era a lealdade desmedida devida ao imperador e à monarquia e exerceram influência forte sobre muitos dos imigrantes mais antigos, o que veio a fortificar ou enfatizar ainda mais o culto ao imperador. 
A instituição central dentro das comunidades nipo-brasileiras recém-formadas era sem sombra de dúvida a "escola japonesa" (nipon gakkeo). A função principal dessa escola no período antecedente à Segunda Guerra era servir como um receptáculo para todos os japoneses residentes no Brasil, e um espaço central para as práticas culturais e principalmente para o culto ao imperador. (Shibata, 1997)

As escolas japonesas eram organizadas e administradas por associações japonesas locais, que foram relatadas por vários entrevistados que delas participavam em São Paulo. Era nessas escolas que a educação geral e, os valores em particular, eram perpetuados, assuntos sociais discutidos, reuniões efetivadas, decisões comunitárias tomadas, cerimônias dos mais variados tipos realizadas, enfim, em que a vida comunitária acontecia. Dentro desse espaço escolar as pessoas reuniam-se em ocasiões importantes como a Celebração do Ano Novo (Shibo Hai), o Dia do Império (Kigen Setsu), o Aniversário do Imperador (Tencho Setsu), festas de aniversário, casamentos e outras festividades variadas. Muitos rituais precediam necessariamente outras atividades na escola: o culto ao Palácio Imperial voltado ao leste, que era considerado único no Brasil; a veneração do retrato do imperador; o ritual da leitura do "Édito Imperial da Educação"; e o canto do hino nacional japonês (kimi ga yo). Participavam os chefes de família nessas ocasiões, bem como seus filhos, demonstrando a importância do espaço da escola para a comunidade em geral, e a função ampliada que adquiriu no Brasil. As escolas japonesas e nipo-brasileiras foram relatadas por todas as famílias entrevistadas, e alguns entrevistados foram criadores dessas escolas, em regiões diferentes da cidade. (Demartini, 2000)

Assim sendo, a escola japonesa funcionava como um centro espiritual para a colônia japonesa. Entretanto, com a política nacionalista de Getúlio Vargas, várias restrições foram colocadas sobre tais escolas: a proibição do ensino na língua japonesa, a necessária presença de professores brasileiros no corpo docente etc.

O clima anti-nipônico ainda relativamente moderado existente desde o ano de 1938 com as pressões da política nacionalista, mas em período em que havia relações diplomáticas e interesses econômicos em jogo entre o Brasil e Japão, foi entretanto progressivamente sendo alterado com a eclosão da Segunda Guerra Mundial; em 19 de janeiro 
de 1941 a Intendência da Segurança Pública de São Paulo baixou um edital para regulamentar as atividades dos estrangeiros naturais dos países do "eixo" que interferia diretamente na vida cotidiana das famílias japonesas, pois determinava modificações não só no plano político, mas em seu estilo de vida, na medida em que ficavam proibidos de falar e escrever na língua de origem, de se reunirem, de trocarem idéias sobre a situação internacional sem autorização, entre outras proibições. Eram medidas que procuravam atingir duramente as práticas culturais do grupo japonês.

Nesse ano foram realizadas evacuações na zona de maior concentração de japoneses na cidade de São Paulo (Rua Conde de Sarzedas) e foi decretado o congelamento de bens dos súditos de países do eixo, medidas estas acompanhadas por inúmeras outras posteriores, que teriam afetado mais o funcionamento de empresas (cooperativas, fábricas, bancos, fazendas etc.). (Uma epopéia, 1992; Morais, 2001; Saito, 1980)

A situação política agravou-se quando navios brasileiros foram afundados, segundo se afirmava, por submarinos alemães, em 1942 e em 1943, levando a novas evacuações de japoneses no litoral paulista e na região da Rua Conde de Sarzedas em São Paulo; paralelamente, os representantes do governo nipônico retornaram ao Japão, ficando os interesses dos súditos nipônicos ligados ao Consulado Geral da Espanha, o que teria provocado um sentimento de desamparo entre os que aqui residiam, já tão pressionados há tantos anos e que foi levando, paralelamente, à idéia de que era necessário organizar a sociedade japonesa do Brasil, por parte de vários membros da comunidade.

O clima de incerteza, acompanhado do sentimento de que era preciso salvar a comunidade nipônica, foi levando ao surgimento de movimentos organizados, já em 1944, como a criação da Shindo Renmei.

A derrota do Japão na segunda guerra mundial marcou profundamente a vida das famílias que residiam em São Paulo: em primeiro lugar, representava o fim da possibilidade de retorno ao Japão, ainda o sonho de muitos (Demartini, 1997); em segundo lugar, implicou em modificações na maneira de viver das pessoas, que reorientaram seus projetos de vida e investimentos para permanecerem definitivamente no Brasil; em terceiro lugar, provocou uma cisão na colônia japonesa, entre os que acreditavam que o Japão havia perdido a guerra - "os derrotistas" ou "esclarecidos" (makegumi) - e os que propagandeavam 
a vitória do Japão, por acreditarem que este jamais se renderia - "os vitoristas" (kachigumi). Estes últimos viviam em grande parte no interior do estado de São Paulo, tendo pouco acesso aos meios de comunicação em língua portuguesa. A Shindo Renmei (liga dos súditos do imperador), uma das associações clandestinas criadas durante a guerra para preservar a cultura e o espírito japonês, que tinha características de organização paramilitar de caráter nacionalista, começou a atuar mais ativamente com o final da guerra: além de propagar a vitória do Japão e a volta à pátria, combatia os "derrotistas", que eram considerados traidores; foram praticados muitos atentados e mortes, levando os que sabiam dos verdadeiros acontecimentos a se calarem. (Uma epopéia, 1992; Dezem, 2000; Morais, 2001)

Desta forma, se durante a guerra os japoneses foram proibidos de discutir/falar pelo Estado brasileiro, no pós-guerra não podiam falar por medo dos próprios compatriotas; é possível que a resistência em falar, ainda hoje, sobre estes acontecimentos também tenha relação com o cerceamento da fala que muitos sofreram, tanto por parte da sociedade brasileira como do próprio grupo japonês. Pode-se afirmar que, após o final da guerra, falar sobre esse período tornou-se um tema "tabu", proibido. (Dezem, 2000)

Impossível detalhar aqui todos os acontecimentos e sentimentos que acompanharam as famílias japonesas nos trágicos anos de existência da Shindo Renmei, originalmente denominada Kôdôsha. A análise de documentos oficiais, artigos e até diários de imigrantes deste período evidencia a tensão que acompanhou todo o grupo japonês no período de 1944 até 1956; a organização atuou com muita força, cindiu o grupo e ainda fez com que os antigos preconceitos contra os japoneses viessem novamente à tona nas primeiras páginas dos jornais e nos debates políticos; estes preconceitos tinham agora um respaldo nas atuações da Shindo Renmei, que durante este período determinaram a morte de 23 pessoas e ferimentos em 86, só no Estado de São Paulo. $\mathrm{Na}$ capital houve ataques, mortes e suicídios, embora a maior parte dos atentados tenha ocorrido em municípios do interior. (Uma epopéia, 1992, p. 292-4)

As repercussões destes atentados, todos envolvendo os japoneses "vitoristas" e os "esclarecidos", foram determinantes na construção de uma imagem negativa do grupo japonês no seio da sociedade paulistana 
e paulista, como se apreende nos noticiários de jornais de 1946, quando ocorreram dois atentados em São Paulo:

"Fanáticos de uma organização secreta japonesa tentaram assassinar nesta capital o ex-embaixador japonês na Argentina. Gestapo japonesa organizada em São Paulo” (Folha da Noite, $1^{\circ}$ de Abril); "Uma organização japonesa está agindo em São Paulo", "Assassinado um industrial no parque Jabaquara", "Outra moradia assaltada na Aclimação" (Diário da Noite, 1 de abril. "Fanatismo nipônico", "Descoberta uma sociedade secreta japonesa", "Prisão de elementos da quadrilha de fanáticos (O Estado de São Paulo, 4 de abril); "Fanáticos nipões agindo em plena São Paulo", "Dezenas de japoneses ameaçados de morte pedem, atemorizados, garantias à polícia paulista", "Afirmam que o Japão ganhou a guerra e querem eliminar os paulistas" (Correio Paulistano, 3 de abril); "Desmascarando as atividades das sociedades secretas japonesas em São Paulo". "A Shindo Renmei tem mais de 100 mil sócios" (Correio Paulistano, 4 de abril); “Quadrilhas de 'Moços Suicidas' desembarcaram em São Paulo para matar japoneses", "O próprio governo do Japão seria responsável pela firme convicção da vitória de seus súditos no Exterior", "As comunidades oficiais não falam em derrota e justificam interpretações, tão bem exploradas pelas sociedades secretas" (Correio Paulistano, 4 de abril); "Prisões em massa na madrugada de hoje (Desarticulação total da 'Shindo Renmei' em São Paulo, "Estão sendo detidos todos os dirigentes da organização no interior do Estado", "Serão submetidos a processo e possivelmente expulsos do país" (Folha da Noite, 5 de abril); "Quatrocentos japoneses já estão nas mãos da Polícia de São Paulo", "A Ordem Política anuncia que a 'Shindo Renmei' foi completamente desmantelada" (Correio Paulistano, 9 de abril); "Um nipo-brasileiro fala: a 'Shindo Renmei' continuará”. (A Noite, 10 de abril) (Uma epopéia, 1992, p. 295-6)

Talvez tenha sido mais difícil ao conjunto da população residente na metrópole entender este movimento, pois justamente aí se encontravam muitas famílias japonesas que já haviam conseguido neste período 
ascender economicamente e estabelecer relações com os demais grupos sociais aí residentes, tendo nesta época uma presença marcante em diferentes aspectos da vida desta metrópole, conforme se pode verificar em quase todas as histórias de vida coletadas. (Demartini, 1997)

Mas este era também um dos motivos que teria provocado a reprovação dos japoneses que consideravam aqueles que estavam satisfeitos com o sucesso obtido no Brasil como apresentando um comportamento absolutamente antipatriótico e imperdoável. Para este grupo, considerado "fanático", a única esperança era reemigrar para a "esfera de co-prosperidade da Grande Ásia Oriental”, no dia em que a história sorrisse para eles, pois confiavam na "Invencibilidade do País Divino", o Japão. E lá iriam viver tranqüilos, sob a égide do Império do Japão. Nessa expectativa deviam suportar vida espartana e penosa, que não envergonhasse sua condição de súdito do Império. Era esse o modo de viver considerado correto e decente." (Uma epopéia, 1992, p. 373)

Neste quadro de tensão, quando chega a notícia da rendição do Japão, esta foi logo em seguida desmentida pelos seguidores da Shindo Renmei (os vitoristas) e difundiu-se entre a comunidade a informação de que a notícia era falsa. $\mathrm{O}$ trecho a seguir, constante de livro escrito por japoneses em 1992, resume o processo de rompimento interno do grupo no Brasil e também a mudança radical das perspectivas e projetos de vida que acompanharam os japoneses no final da Segunda Guerra Mundial e na década de 1950 :

"Com exceção daqueles que já vinham acompanhando o curso da guerra com apreensão, a minoria que lia jornais brasileiros e ouvia as transmissões radiofônicas em português, todos os demais acreditaram na versão vitorista.

A todo momento chegavam pormenores sobre o fim da guerra, as condições para a rendição do Japão etc. Mas, para os japoneses que haviam recebido a educação de 'súdito do império', baseada no nacionalismo mais extremado e na crença de 'Japão, país divino' e que, vivendo no estrangeiro, tinha aguçada a sua consciência de nipônicos, reconhecer o revés da pátria representava, no mínimo, uma atitude antipatriótica.

As atitudes e palavras dos que, reconhecendo a realidade da derrota, pregavam a necessidade de procurar o reerguimento 
moral e material dos japoneses, partindo dessa trágica realidade, reiniciando uma nova vida, representavam, para os elementos vitoristas radicais, gestos e pregações intoleráveis, de verdadeiros demônios... Portanto, a morte desses elementos antipatrióticos que propagavam a derrota do Japão significava o cumprimento de 'uma ordem do Imperador'.

Foi assim que, na história dos 80 anos da imigração japonesa no Brasil foram perpetrados atos terroristas, em que patrícios assassinaram patrícios, acrescentando uma página negra, inapagável, trágica e triste, que abalou profundamente não só a comunidade nipônica como a própria sociedade brasileira." (Uma epopéia, 1992, p. 375-6)

O período do pós-guerra significou para muitas famílias japonesas entrevistadas, mesmo as que residiam em São Paulo, uma profunda revisão em seus projetos de vida e na educação pensada para os filhos, especialmente entre os que almejavam anteriormente regressar ao Japão. Houve uma intensificação dos interesses voltados para a educação nacional, visando os níveis mais elevados do ensino (Demartini, 1997).

A crise e os problemas suscitados pela atuação da Shindo Renmei levaram ao resgate e fortalecimento da antiga discriminação existente na sociedade brasileira contra os imigrantes japoneses. Este fato podese constatar claramente nas falas dos representantes na Assembléia Nacional Constituinte em 1946, ao discutirem a nova constituição e a emenda $n^{0} 3.165$, que pretendia vedar inteiramente a imigração japonesa para o Brasil; exemplificamos com alguns trechos das falas de políticos na sessão de 27 de agosto de 1946, evidenciadoras da forte discriminação que voltou à tona:

Vários oradores nesta Assembléia tratando do assunto mostram que os japoneses são, como o enxofre, insolúveis, não se deixando assimilar. Irão constituir quistos sociais. (Adroaldo Costa - PSD)

(Corte da parte inicial do aparte). A prova evidente de que são nocivos ao Brasil, reside em que, ainda hoje, mesmo oriundos de país derrotado, ainda nos estão dando trabalho. É de estranhar que ainda apareçam aqui defensores dos inimigos do Brasil. (Trocam-se outros apartes). (Rui Almeida - PTB) 
A matéria pode ser regulada em lei ordinária. Não sou favorável à imigração japonesa; ao contrário, sou contra ela, no momento. Acho, porém, iníquo incluir esse dispositivo no texto constitucional. (Aureliano Leite)

O Sr. José Augusto - [...] por gente que não se incorpora ao Brasil, que aqui está formando quistos raciais, representando, assim, sempre e cada vez mais, um perigo para a própria existência da nossa nacionalidade. (Palmas) (corte). (Aureliano Leite) Todos estamos de acordo em que, no atual momento histórico, a imigração japonesa é indesejável. (Hamilton Nogueira - Senador pela UDN)

É nociva. (Rui Almeida)

Será uma calamidade. (Lê trecho do pronunciamento do Sr. Santiago Peralta, diretor do Serviço de Imigração Argentina.) - 'Não queremos uma imigração ao acaso; queremos nesse caso, agir fria, técnica e cientificamente...' (corte da parte central do trecho)... Por isso, defendo a emenda, que é de muitos membros desta Casa, e que impede a entrada no país de elementos que têm sido aqui, conforme ainda agora os fatos demonstram, elementos de perturbações e de desordem, e assim totalmente nocivos ao interesse nacional. (Muito bem; muito bem, Palmas. O orador é cumprimentado). (José Augusto) (Uma epopéia, 1992, p. 306-8)

As discriminações acima exemplificadas com as palavras de políticos da época ignoravam as realizações concretas dos japoneses em São Paulo e sua importância econômica e cultural no desenvolvimento da cidade. ${ }^{3}$

Foi considerando todo este contexto acima, que procuramos verificar o que e como os entrevistados falavam do período em que foram duramente discriminados pelo Estado e pela sociedade brasileira, como

3 Só para exemplificar, eram eles os grandes produtores de legumes, frutas e verduras que abasteciam a região metropolitana, o interior, além de exportarem (representavam $42,3 \%$ do total de agricultores da capital); detinham grande parte dos boxes do CEAGESP, eram donos de grande parte de lavanderias, lojas, armazéns, além de bancos, indústrias, cooperativas etc. (Uma epopéia, 1992, p. 461533). Em síntese, sem eles a cidade poderia sofrer colapso de abastecimento especialmente de produtos agrícolas e de serviços. 
vimos, e em que o grupo se dividiu. O que nos interessou explorar a partir das entrevistas realizadas foi justamente este aspecto: que visão sobre os acontecimentos tentaram transmitir a partir das narrativas muito mais amplas sobre suas trajetórias de vida? Como já explicitamos anteriormente, ao realizarmos as entrevistas não houve uma preocupação de nossa parte em direcionarmos os relatos diretamente para esse período da vida dos entrevistados; pedíamos que falassem livremente sobre sua vida, a de sua família, demonstrando interesse por todos os aspectos e temas abordados; dessa forma, analisar os relatos sobre este período "dramático" da colônia em São Paulo assumiu novos significados, pois os entrevistados não foram indagados diretamente sobre os mesmos.

Por tratar-se de estudo em que estávamos mais preocupados em reconhecer e explorar a diversidade de representações, a variedade de vivências e estratégias adotadas que tentar encontrar padrões uniformes na vivência do grupo de origem japonesa, pareceu-nos promissor adotar a perspectiva de Franco Ferrarotti (1984) de explorar o social contido nas histórias de cada um dos personagens, para a partir daí apreender a trama do social:

"Esta é uma questão sobre a qual eu tenho dialogado com D. Bertaux que fala em estandartização. Para mim o mais importante é a questão entre a relação e o fragmento e a totalidade. No fragmento já tem a totalidade. Na profundidade da experiência a mais individualizada, existe a concentração, a reestruturação ou o estenograma de toda uma cultura, de toda uma vida social. Como fazer do indivíduo caótico, aparentemente caótico, a ordem social não somente a ordem interiorizada mas a estrutura da ordem que torna o indivíduo mesmo o mais marginal, suscetível de ser compreendido, de se fazer compreender, na globalidade das significações. Não há totalidade pré concebida sem fragmentos, mas em todo fragmento há a nostalgia da totalidade." (Ferrarotti, 1984, p. 30; grifo nosso)

A análise levou-nos a constatar o fato, fundamental, de que foram poucos os que, durante as entrevistas, falaram detidamente sobre os problemas que acompanharam o grupo japonês durante a Segunda Guerra Mundial e, principalmente, após a mesma. 
Os entrevistados ainda mostram resistência e não gostam de comentar o período. Assim como em outros estudos, a noção de silêncio é importante neste caso. O movimento da Shindo Renmei, que provocou cisão na colônia japonesa, opondo muitas vezes mortalmente pessoas dentro de uma mesma família ou grupos de convivência, deixou marcas nas memórias dos entrevistados. Falar sobre esses acontecimentos evoca especialmente entre os mais velhos não apenas lembranças de momentos dolorosos, que a memória tenta esquecer, mas também sentimentos de vergonha: à imagem de um povo ordeiro e trabalhador, que tentaram construir e vincular enquanto imigrantes desde que chegaram ao Brasil, tais acontecimentos contrapõem momentos de brigas, delações, perseguições e assassinatos praticados dentro do próprio grupo. Preferem, em seus relatos, falar sobre a importância da solidariedade entre os nipo-brasileiros nos dias atuais e sobre as estratégias que desenvolveram para a manutenção dos laços de união do grupo e das tradições japonesas orientadas nesta direção. Talvez, para muitos, não falar sobre estes momentos traumáticos se constitua em uma das formas visualizadas de ir apagando as diferenças e as divergências, para concretizar a ainda recente "harmonia" do grupo. Como já apontaram alguns autores (Schwarzstein, 2001), a convivência com a recordação do passado pode ser difícil, e não é suficiente sobreviver fisicamente para que o trauma possa ser abandonado.

Durante as entrevistas realizadas com jovens das mesmas famílias (terceira geração), também observamos que não havia referências a estes acontecimentos, quando falavam dos pais e da história da família. A memória familiar parece não incorporá-los.

A análise dos relatos orais dos entrevistados que conseguiram falar sobre os problemas e as discriminações pelas quais passaram, mesmo poucos e sucintos, permitiram-nos, contudo, explorar um pouco mais as marcas deste período de guerra e pós-guerra em suas vidas, e, especialmente, as representações que elaboraram mais recentemente sobre o mesmo. Do conjunto dos relatos dos entrevistados, destacamos aqueles que de alguma maneira se referiam às mesmas. Como se poderá verificar, foram relatos de homens e de mulheres ligados a diferentes atividades durante o período.

Embora tenham vivenciado experiências muito diferentes, de uma forma geral todos foram submetidos às mesmas medidas legais e 
discriminações acima citadas. Como se viu, nem as leis nem os discursos discriminadores estabeleciam ou aceitavam diferenciações internas ao grupo; constituiu-se neste período uma representação "homogênea" negativa sobre o mesmo, que era veiculada para a sociedade brasileira: era o "perigo amarelo".

Entretanto, à visão de uma colônia japonesa homogênea, os relatos dos entrevistados permitiram contrapor os dilemas e conflitos do grupo, que levaram à sua extrema fragmentação, desconstruindo a imagem padronizadora sobre o imigrante japonês. Tais relatos evidenciaram não só que a maneira como viveram os acontecimentos que atingiram o grupo no período em pauta foi variada, conforme a maneira como cada um estava inserido no contexto paulista e as relações já estabelecidas com a sociedade local, como também as representações e leituras recentes que fazem dos mesmos. Para alguns poucos, como veremos abaixo, o período do Estado Novo e a Segunda Guerra Mundial (1937-1945) foi mais problemático; para outros, em maior número, foi o período do pós-guerra, durante a atuação da Shindo Renmei em São Paulo.

De modo geral, os entrevistados, que residiam na época na metrópole de São Paulo, contaram que durante o Estado Novo e a Segunda Guerra Mundial foram afetados de alguma maneira pelas medidas controladoras do governo, mas alguns também relataram com certa ironia e até em tom de brincadeira, como desenvolviam estratégias para burlar as leis e a vigilância. Todos eles também dão indicações de como foi justamente durante este período que conseguiram estabilizar-se economicamente na metrópole, seja adquirindo terras, desenvolvendo atividades liberais, comerciais etc.; neste período, a segunda geração, nascida ou não no Brasil, já havia cursado ou estava cursando as melhores escolas de ensino médio e universitárias do país, em um processo de ascensão social intenso. Já haviam estabelecido, assim, vínculos fortes com a sociedade local, o que lhes permitia "burlarem" as leis autoritárias com certa facilidade.

O relato de um dos entrevistados que residia com a família em propriedade rural na região próxima a Taboão da Serra, onde eram agricultores e criadores, exemplifica bem o que muitos fizeram neste período da guerra: assim como eram vigiados, também "vigiavam" as autoridades policiais: 
"Casei no meio da guerra. [...] uma pessoa [ficava] na rua ... entrava pra avisar, não é? [risos] porque não podia reunir mais que cinco pessoas, não é? [...] Quem fez o casamento foi o escrivão do cartório de Santo Amaro, então ele veio aqui e fez nosso casamento. Ele era nosso vizinho. [...] Vieram mais ou menos vinte pessoas". (Entrevistado S.)

Atitudes como esta foram narradas por outros entrevistados; um deles, que foi professor de uma escola japonesa com mais de cem alunos, de 1938 a 1942, afirmou que a escola em que lecionava mantinha um "olheiro" para avisar quando algum estranho se aproximava; desta forma, podia ensinar na língua japonesa (Entrevistado Y). Tinham também outra estratégia: "É, porque naquela época, como (havia) proibição, era escondido, e o professor trabalhava também, maioria criando galinhas ou lavouras, né?" (Idem). Outros mantiveram professores particulares para os filhos dentro de suas próprias casas, não configurando assim uma "escola japonesa".

É interessante destacar que durante todo o período do nacionalismo, da Segunda Guerra Mundial e do pós-guera, muitas escolas japonesas continuaram funcionando graças às estratégias que pais e professores desenvolveram para burlar as leis discriminatórias. Além de colocarem os vigias, também procuravam manter laços de amizade com pessoas importantes da cidade e do governo.

Um entrevistado que residia próximo a Taboão da Serra contou como seu pai fundara uma escola ali, logo após sua chegada:

"Ele [o pai] que trouxe a escola que nós temos no bairro, ele que fez muito esforço [para criar] a Escola Pública [no bairro de Taboão da Serra]. Era pública, mas era japonesa, também. Quer dizer que era escola pública e ficava junto com a japonesa. Então, quer dizer que eles construíram uma parte e deram pra escola pública e a outra era escola japonesa. [...] [A escola chamava-se] Escola Mista Nipo-brasileira. [...] Meu pai veio aqui em 30... Em 33 já construiu escola." (Entrevistado S.)

As aulas eram ministradas nos dois idiomas e a escola era também freqüentada por crianças brasileiras. Essa escola era mantida pelas doações da comunidade, que pagava o salário do professor de japonês, 
pois a professora que ensinava português era paga pelo Estado. Além das doações da comunidade da região próxima a Taboão da Serra, houve, inicialmente, a ajuda do cônsul, porque o pai do entrevistado e o cônsul eram amigos. Durante a guerra essa escola não foi fechada, graças, em grande parte, "ao apoio do inspetor de ensino da região, Francisco de Lima”, com quem os japoneses estabeleceram vínculos ao longo do tempo.

A grande preocupação dos japoneses com a educação de seus filhos estava, também, fortemente presente do outro lado da cidade, na grande colônia de Itaquera; antes de as crianças freqüentarem um grupo escolar ou uma escola particular de nível primário, iam à escola dominical criada pelos moradores. Os relatos sobre essa colônia de Itaquera, onde residiam centenas de famílias japonesas desde a década de 1920, evidenciam bem as estratégias adotadas para se enfrentarem as pressões. O entrevistado que nos foi designado para falar sobre a história do grupo nesse local, conta:

"Geralmente a família japonesa se preocupa muito pela educação, então começou com uma escola japonesa, escola nossa. Veio um professor de fora e criamos uma escola que chamava escola dominical, aos domingos. Então eles reuniam alunos e davam [...] Isso continuou alguns anos, de 1932 a 35. Esta escola dominical foi idealizada por um professor, ele morava em Pinheiros, chamava-se Kishimoto. [...] Esse senhor, eu não sei [por]que eu era aluno, era menino, mas ele veio à colônia e fundou uma escola. [Funcionava em] uma casa de uma família particular. [...] Não sei quanto tempo ele [professor] ficou. [...] Depois nós transferimos ao professor Kuzita, esse senhor Kuzita morava aqui, não é?” (Entrevistado T. K.)

Com o passar do tempo a escola deixou de ser dominical e passou a "funcionar assim semanal, dia de semana, duas, três vezes por semana também. [...] era um curso de opção dos alunos, da família. Os pais pagavam uma mensalidade para os filhos estudarem porque tínhamos que manter professor." (Idem)

A primeira escola nipo-brasileira da colônia surgiu justamente em 1938; essa escola particular de tipo isolada foi lembrada também por 
outro entrevistado, um senhor nissei que aí nasceu e chegou inclusive a nela estudar:

"[...] foi mantida pela comunidade, então a comunidade fazia escola japonesa, mas se preocupou pela escola, educação nacional... E fundou-se aqui uma escola particular... tinha uma professora aí. [...] E funcionava na sede, onde nós construímos para estudar. [...] Havia uma professora dando aula para todos, ela tinha que dividir. Era sacrifício..." (Entrevistado N.)

Como a escola não podia oferecer os quatro anos do curso primário, houve o interesse por parte dos moradores para que se tornasse pública. Para tanto foi necessária uma autorização do inspetor estadual.

"Nós não podíamos fazer 4 anos, [porque era] escola isolada. Aí entramos para a Secretaria da Educação, aí a Secretaria da Educação nomeou um inspetor, inspetor que vinha, era através desse inspetor do Estado que nós tínhamos autorização para manter funcionando. [...] A escola seguia o programa oficial. Só que nós não podíamos fornecer diploma, não é? E com isso o número de alunos aumentou, contratamos, um, dois, chegou até a três professores na escola. [...] E nisso [a colônia] foi entrando em contato com o governo para ver se o governo mantinha a escola. Porque nós éramos fiscalizados através de um inspetor, nós sempre tivemos um inspetor. $\mathrm{O}$ inspetor escolar é que autorizava o funcionamento da escola particular. [...] No fim do ano, para que os alunos pudessem passar de uma série, de um ano para o outro, a banca examinadora era fiscalizada pelo inspetor escolar, não inspetor de alunos, inspetor escolar que vinha da delegacia de ensino, mesmo, não é? [...] [A criançada] pegava as provas e fazia, mas não se entregavam os diplomas. [...] acontece que o governo [paulista] aceitou, mas não tinha professora que vinha porque era isolada, [...] tinha que andar pra condução. Então a colônia, a comunidade prontificou a dar um táxi. Então o governo fornecia a professora, nós fornecíamos alojamento... o galpão onde funcionavam as aulas e a condução da professora." (Entrevistado T. K.) 
Pelos relatos desse entrevistado podemos perceber que a fim de poderem continuar ensinando a língua japonesa às crianças, os dirigentes da colônia utilizaram-se de um artifício, qual seja, transformar a escola particular em escola pública, o que poderia significar para a população brasileira um processo de assimilação dos imigrantes japoneses. Assim, não haveria nenhum motivo para o governo fechar a escola, mesmo durante a Segunda Guerra, pois a escola já era pública, mantida com doações dos pais e com apoio do governo do Estado, e sem nenhum apoio do governo japonês. Como foi sintetizado pelo entrevistado:

"Como estamos no Brasil, educação tem que ser o primeiro... A língua nacional, a língua pátria e... Começamos com escola particular, da escola particular fomos entrando sempre em contato com o governo e até o governo chegar a receber e oficializar o Grupo Escolar. Então nós oficializamos o primeiro Grupo Escolar da colônia e me parece que nessa ocasião o professor era normalista, que eu falei. Em 1949 oficiou dessa escola particular para um Grupo Escolar da Colônia de Itaquera. E, talvez em sessenta e poucos conseguimos um prédio próprio. O prédio então funcionava naquele lugar que a senhora foi visitar (o clube), o governo fez o galpão de madeira e o prédio funcionava ali." (Entrevistado T. K.)

No final dos anos 1950, a Colônia doou $10 \mathrm{mil} \mathrm{m}^{2}$ de terra para o Estado, a fim de que se construísse o Grupo Escolar da Colônia de Itaquera, uma escola com cerca de oito classes. A partir do momento em que a escola passou a ser do governo, a comunidade não podia mais contratar os professores que quisesse, mas criou uma Associação de Pais e Mestres.

Foram também citadas escolas primárias completas mantidas por particulares, como a Escola Primária Taisho, talvez a mais antiga escola primária japonesa completa; ela foi criada por volta de 1914, contando com apenas três alunos que pagavam uma mensalidade de quatro mil-réis. Sua fundação oficial data de outubro de 1915, mas foi somente no ano seguinte que conseguiu um endereço fixo e mudou-se para o número 48 da Rua Conde de Sarzedas, no andar térreo de um sobrado que ficava no fim da ladeira; mais tarde essa escola mudou-se para a rua São Joaquim. Em janeiro de 1919 a Taisho foi reconhecida como escola 
particular, e no final do ano, em dezembro, a professora Antônia dos Santos, que era negra, começou a dar aulas de português (Handa, 1987). De acordo com um ex-professor entrevistado, Takeshita, a Escola Taisho foi criada pelo professor Miyazaki, que "era professor formado de escola de... língua estrangeira lá no Japão. Depois veio aqui... ele inventou, essa escola, começou a ensinar. Isso foi porque tinha necessidade, naquele tempo tinha, ainda não existia nenhuma escola japonesa. Foi a primeira escola japonesa de São Paulo. Para filhos de japoneses." (Entrevistado Ta.)

Havia classes de manhã e à tarde. De manhã as aulas duravam quatro horas e à tarde de duas a três horas. As aulas de português eram dadas por professores brasileiros, e enquanto uma turma aprendia o idioma japonês, a outra aprendia o português. Os professores levavam as crianças para passear no Parque da Aclimação, local onde se realizava o undôkai - tradicional festejo anual para se comemorar o aniversário do Imperador. A Escola Taisho parecia não ter, nessa época, qualquer contato com outras escolas da cidade, e, segundo o professor entrevistado, o governo não exercia controle sobre as atividades docentes. A escola parecia funcionar de acordo com seus interesses, ensinando o português, mas empenhando-se na transmissão dos conhecimentos através da língua japonesa. O controle mais efetivo sobre sua atividade vai se manifestar na década de 1930, durante o Estado Novo.

Uma entrevistada nissei (nascida em Promissão, em 1914, que não aprendeu o japonês porque seu pai achava que ela devia saber o português), chegou a dar aulas no ano de 1938-1939, nessa famosa escola, para alunos do $3^{\circ}$ ano que já sabiam falar o português. De acordo com essa senhora:

"A Escola Taisho seguia a linha dos Grupos (estaduais), mesmo porque de lá os alunos iam entrar no ginásio, ginásio comum. Lá só tinha o primário. [...] Então a gente tinha que seguir o programa de ensino que dava normalmente no ensino. E geralmente a gente conseguia. [...] Dava História do Brasil, como se todo mundo fosse brasileiro mesmo, só que... alguns faziam aulas de japonês. [...] Nós éramos quatro professoras brasileiras e depois tinha os professores japoneses, que davam aulas de japonês, eles seguiam o programa do Japão.” (Entrevistada C.) 
Outra escola particular do bairro Pinheiros que pode ser comparada à Taisho sofreu interrupção com a Guerra. Uma entrevistada disse que se lembrava de sua permanência na Escola Japonesa Yoseguaken durante três anos (1936-1939), tendo entrado na escola "quando tinha oito anos" (Entrevistada K.K.T.). As aulas eram ministradas em japonês e havia muitos alunos. As turmas eram mistas e o número de meninos e meninas era praticamente igual. Quando indagada sobre a fundação da escola esta senhora disse que já existia antes de 1936. As crianças iam à escola na parte da manhã e ficavam aí por quatro horas. Além de música e gramática japonesas, havia também as aulas sobre a história e a geografia do Japão dadas por três professores, que falavam, ensinavam e escreviam em japonês. Para realizar o tradicional undôkai, a escola alugava um campo próximo para as crianças; além disso, havia teatrinhos para os pais, em japonês. Essa escola funcionava em regime de externato e internato, pois: "Além das crianças que moravam na capital, também tinha meninas do interior, que ficavam internadas na escola." (Entrevistada K.K.T.)

Eram oferecidos às crianças seis anos de estudo e depois mais dois anos como colegial. O professor Aki, diretor da Escola Japonesa Yoseguaken:

"[era] formado, tem que ser formado. [O governo japonês ajudava na manutenção da escola, tanto que] ele (professor Aki) recebia também do... como chama? mesada [o subsídio do governo japonês] lá do Japão também. [...] depois começou essa guerra [a Segunda Guerra Mundial] já não recebeu mais [...] quando começou essa guerra aí, aí todo mundo, espalhou tudo. Na Segunda Guerra. Aí esse professor Aki, ele foi morar em Pinheiros. Aí ele dava aula assim escondido, não é? Depois não deu mais. [...] Daí ficou tudo espalhado, então. Essa escola ficou funcionando até essa guerra. [...] Aí tinha que fechar não é?” (Entrevistada K.K.T.)

A Escola Yoseguaken foi fechada, portanto, no começo da Segunda Guerra Mundial.

É necessário observar que, embora as duas fossem consideradas escolas particulares japonesas, parecia haver uma diferenciação entre elas, uma vez que a Taisho incorporava professores de língua portuguesa. 
Não temos condições de avaliar em que medida este fato teria influenciado no fechamento da Escola Yoseguaken, última durante o período da guerra e, até que ponto, por serem escolas que pareciam ter maiores vinculações com o governo japonês, teriam deixado de desenvolver (como contatamos no caso das escolas isoladas) estratégias que permitissem sua aceitação e incorporação no sistema oficial de ensino, embora os valores e a cultura japonesa aí continuassem presentes.

O caso relatado por outra entrevistada, fundadora de famosa escola para japoneses em São Paulo, mostra como mesmo escolas particulares conseguiram se adaptar às pressões da época. Nascida no Japão e tendo vindo para o Brasil com o marido no início dos anos de 1930, Michie Akama fundou a Escola de Corte e Costura Akama, em 1932 (atualmente é o Centro Educacional Pioneiro, fazendo parte de uma fundação, juntamente com o Centro de Língua Japonesa). A idéia de criar uma escola surgiu após dona Akama, que era formada no Japão, e o marido, um oceanógrafo, terem ficado um ano em Registro, interior de São Paulo, e visto "moças sem objetivos na vida, nem possibilidade de estudar".

Ao chegar à cidade de São Paulo, o casal criou uma escola de corte e costura para moças, do tipo pensionato. Em agosto de 1933, as aulas não mais se restringiam a corte e costura, pois havia também aulas de japonês, trabalhos manuais, culinária, etiqueta, tênis etc. - enfim, tudo o que era necessário para uma futura dona-de-casa. A escola atendia à clientela da colônia japonesa do interior, sendo que $70 \%$ das alunas eram de origem japonesa. A partir de 1935, com a institucionalização dos exames de habilitação do magistério profissional de corte e costura, a escola criou um currículo para preparar as candidatas para tal exame. Aproximadamente 40 jovens conseguiam aprovação anualmente, e depois abriam suas escolas no interior do Estado. (Álbum Comemorativo, 1985)

Segundo a entrevistada, durante a Segunda Guerra Mundial a escola ficou proibida de ensinar o japonês, mas continuou funcionando e crescendo. Após o fim da Segunda Guerra, em vez de adotar prioritariamente matérias tipicamente japonesas, começou a seguir o mesmo currículo do curso médio brasileiro, com aulas de latim, francês, inglês e português, em razão do grande interesse da comunidade japonesa de se integrar à sociedade brasileira. O governo japonês nunca deu nenhuma 
ajuda à escola, alegando - segundo dona Akama - "falta de ética para com o governo brasileiro".

A entrevistada conta, entretanto, que foi em virtude do movimento Shindo Renmei, que enfrentou sérios problemas, pois acreditava na derrota.

A política nacionalista brasileira e a situação de guerra, embora tenham implicado dificuldades para as famílias e escolas japonesas, parecem não ter causado na metrópole de São Paulo alterações tão profundas no tocante ao campo educacional, ao menos não logo de imediato, pois muitas das escolas aqui existentes, particulares ou "nipo-brasileiras", continuaram em funcionamento. Se no interior a freqüência às aulas era realizada às escondidas e à noite, caracterizando uma estratégia de resistência dos japoneses necessária para poderem continuar com um ensino "seu", em São Paulo, tanto na região central como na periferia, parece que as estratégias foram outras - os japoneses conseguiram estabelecer vínculos com as autoridades escolares nacionais que lhes permitiram manter o funcionamento das escolas por eles criadas, mantidas e controladas. As mudanças no campo educacional foram ocorrendo em virtude das mudanças dos projetos das famílias.

Sobre o período da Guerra, três entrevistadas falaram de problemas enfrentados. A única entrevistada que afirma ter sua família sofrido muito com as leis restritivas era, justamente, pertencente a uma família pobre, o que não ocorria com as demais, que já estavam estabilizadas economicamente. Trabalhava, segundo relata, em uma indústria, que foi obrigada a reduzir o número de operários japoneses, substituindoos por brasileiros, para atender às exigências das cotas mais restritivas de estrangeiros; ela foi uma das que perdeu o emprego. Também outros dois irmãos perderam o emprego: um trabalhava no Consulado Japonês e outro numa firma de exportação.

"Eu, por exemplo, fui vítima da guerra. Diretamente não digo, porque ninguém foi à guerra, nada, mas eu fiquei desempregada no ano que começou a guerra. Porque eu estou com essa língua japonesa, máquina, escrevo em máquina japonesa, agora esse jornal, mas onde é que tem? Tudo proibiu, sabe? E essa companhia que eu trabalhava, fechou. Fechou porque tudo era em japonês e era uma lei, que dividiu em brasileiro e em japonês, sabe? Que podia trabalhar? Três 
brasileiros podem trabalhar e um japonês, então eu, por exemplo, tirava documento e então entramos lá. Então tem que arranjar três para poder eu trabalhar, aí ficou muito difícil para a empresa também [...] Só que não tinha muito empregado, era muito pouco, sabe? A maioria era, tinturaria, tinha uns que trabalharam em outras coisas. Agora, esse que eu trabalhei, hoje é o Banco América do Sul. Então a maioria que trabalhava lá... Tem um que até hoje trabalha lá. Eu parei de trabalhar nesse emprego bom que eu tinha, porque eu ganhava muito bem, porque um trabalho diferente, não é? Aí, por causa da guerra eu parei. Por isso que tudo... Se não tivesse guerra que eu... continua trabalhando, um pouco ainda. Mas a guerra. [...] O pior é que meu irmão que é japonês, esse que eu falei agora, que tem outro irmão que veio do Japão, não é? Eles trabalharam então no consulado. Ele era conselheiro do consulado. Também fechou. Primeiro fechou foi aí no consulado, depois fechou aonde ele estava. E a outra minha irmã também trabalhava numa firma de exportação também parou. Você vê que três na família menos... Minha irmã que trabalhava como enfermeira foi a única que ficou como empregada, não é? É, porque esta história mesmo assim sofreu um pouco, porque que era dos japoneses virou e mudou muita coisa...” (Entrevistada R.T.)

Por outro lado, uma entrevistada contou-nos que neste mesmo período conseguiu empregar-se, embora ainda fosse menor de idade, para ajudar no sustento da família: ela era a única "brasileira". Seu pai, que só falava japonês, foi preso um dia, durante a guerra, para averiguações, sendo levado para a delegacia da Rua Gusmão. Ela não teve problemas no emprego, nesta fábrica de estojo para costura, que era de uma japonesa. As autoridades estaduais só exigiram da dona que esta registrasse a entrevistada conforme as leis trabalhistas. Ficou neste emprego cerca de dez anos.

"Aí começou a guerra, não começou? E meu pai então conhecia japonesa... e essa japonesa da rua Santa Efigênia, no 264. Essa japonesa comprou essa loja e tinha fábrica de estojo para costura, naquele tempo, no Brasil só tinha essa loja. Eu 
entrei aí como empregada, cozinhando, arrumando aí. Eu entrei com treze anos. Aí... eu era menor, aí veio o fiscal... ver os empregados, não é? Aí a filha do dono trabalhava, aí veio o fiscal falou: 'Quem é ela?' 'Essa é minha filha', patrão falou. 'E esta?' 'Empregada.' 'O senhor sabe que... hoje empregada tem que registrar.' Eu tirei carteira de trabalho de menor." (Entrevistada K.K.T.)

Apontaram problemas significativos em suas vidas os que haviam chegado do interior, ainda com dificuldades financeiras, e os que tinham alguma atividade ligada ao governo japonês e aos meios de comunicação: foi o caso da família de outra entrevistada cujo pai, que era jornalista, tinha montado um jornal quando vieram para a cidade de São Paulo, em 1937. Ela relata que, com a guerra, o jornal foi proibido; mas seu pai fazia panfletos em japonês, e os distribuía:

"Eu sei que quando começou a guerra... no mesmo dia que o Japão entrou, eles proibiram todos os jornais alemães, italianos e japoneses. Meu pai ficou triste... assim mesmo ele fazia panfletos... em japonês. Ia distribuir [...] aí meu pai não pode mais trabalhar e ... não sei como é que foi, viu?” (Entrevistada C.O.)

Ela conta que os de sua família começaram a trabalhar em "coisas humildes, porque era muito difícil para o japonês arrumar emprego". Mesmo assim, durante este período seu pai começou a escrever vários livros, dentre eles um dicionário tupi-guarani/japonês, que teve muita saída. O que é interessante anotar, em seu relato, é que ao ser indagada sobre a distribuição de panfletos clandestinos e se o pai havia sido preso, ela afirmou: "não foi. A mágoa dele é que nunca foi preso".

O ressentimento, neste caso, não se referia às perseguições e proibições legais, mas ao fato de não o terem prendido. A prisão talvez significasse, para ela, a demonstração de pertencimento ao grupo, de identidade aos seus valores e cultura.

O tom de brincadeira e ironia geralmente desaparece dos relatos quando os entrevistados falam do pós-guerra, período em que as medidas legais restritivas do Estado brasileiro foram diminuindo, porém de forte atuação da Shindo Renmei. Como já afirmamos, com o final da guerra, os japoneses vitoristas, que acreditavam na vitória do Japão 
e que constituíam aproximadamente $70 \%$ dos imigrantes, opuseram-se aos "derrotistas" ou "esclarecidos", grupo que tinha mais acesso aos meios de comunicação em português e que propagava que o Japão havia perdido a Guerra. Nossos entrevistados vivendo na capital, encontravam-se muitos deles desse lado. Muitos, como observamos, já mantinham estreitas relações com autoridades nacionais.

Um dos entrevistados (M.Y.), que morava nesta ocasião em uma região do interior em que havia forte concentração de japoneses, Bastos, presenciou a atuação violenta da Shindo Renmei e relatou como um dos moradores da colônia, um ex-coronel, foi assassinado porque tentou explicar para os vizinhos que, desta vez, nesta guerra, o Japão fora derrotado. O entrevistado afirmou, várias vezes, que as pessoas na colônia, no interior distante, ficaram sem notícias, o que levou ao surgimento de rumores de que o Japão teria vencido. Dá uma justificativa (a ausência de informações) para o clima de insegurança e violência que se instaurou.

Alguns dos entrevistados foram considerados derrotistas e sofreram sérias perseguições por parte dos vitoristas. Um deles (K.), pessoa importante da colônia japonesa em São Paulo, passou dois anos com guarda-costas para evitar as tentativas de morte. É interessante notar que o entrevistado não se alongou muito sobre o assunto (embora sua entrevista tenha sido longa) e tentou, parece-nos, dar uma interpretação aos fatos de modo a minimizá-los: os vitoristas foram mostrados como ingênuos ou ignorantes, não como inimigos e, menos ainda, criminosos.

"Se contar minha vida, minha vida foi bastante acidentada, agora, houve aquele... Quando houve derrota do Japão... em 45, japoneses não acreditaram. Conhece esta história, né? Precisava condenar esse fanatismo, então queriam me matar.

$\mathrm{P}$ - Como é o nome mesmo daquele movimento? É Shindo Rinmei. Eu andei... Trabalhei na Cotia [cooperativa], por isso que não fui morto. Polícia central colocou guarda-costas para mim, me esperavam aqui para me matar. Dois anos. [...] Dois anos eu tive guarda-costas. Esse guarda-costa chegava aqui de manhã, saía junto, ia na [cooperativa] Cotia, ficava no escritório. 
P - Ficava acompanhando o dia inteiro?

O dia inteiro. Almoço vinha aqui, era para mim e para ele, almoçávamos juntos...

$\mathrm{P}$ - Qual era o objetivo deles?

Têm alguns, esses digamos, fanáticos, ingenuamente fanáticos, outros sabiam que o Japão foi derrotado, mas eles tinham acumulado muitos yens, eles não podiam dizer que Japão foi derrotado, senão aquele yen... Era papel, não tinha praticamente valor.

$\mathrm{P}-\mathrm{E}$ eles estavam comprando para poder voltar para $\mathrm{O}$ Japão e levar este dinheiro para lá?

Mas ele já viu que não podia, então ele precisava passar para alguém. Também tinha outro, como imigrante humilde, ele achava que era a oportunidade para se voltar contra esses dirigentes.

$\mathrm{P}-\mathrm{E}$ esse movimento então demorou dois anos?

Demorou.

P - E quem é que chefiava esse movimento? Pegou só o estado de São Paulo ou não?

É uma história longa, longa, né? É só japonês, aqui. Também alemães tinha, também.” (Entrevistado K.)

Não foram, entretanto, dadas maiores informações durante a entrevista.

Também outro entrevistado (S.) que residia com a família na periferia de São Paulo, perto de Taboão da Serra, trabalhando como agricultores e criadores em terra própria, considerou que todos foram enganados, vitoristas ou derrotistas. Segundo ele, alguns japoneses sem caráter aproveitaram-se da ignorância dos compatriotas para explorálos após a guerra; sua família tinha um empregado, também japonês, que ganhou muito dinheiro enganando os japoneses do interior do estado; esses, acreditando que o Japão havia ganho a guerra, vendiam suas terras em troco de "ienes" (dinheiro japonês que não valia mais nada), para voltar para o Japão. Muitos chefes de família suicidaram-se após descobrir que haviam sido enganados pelos próprios compatriotas e perdido tudo; não podiam voltar para o Japão, nem tinham dinheiro para viver aqui, segundo ele. 
Este entrevistado também transmite, em sua fala, a idéia de que foi um grupo de fanáticos, e de enganadores, quem participou da Shindo Renmei:

"Eram tudo fanático, eram tudo fanático. [...] tinha aquele bloco... que não se dava bem com a gente, não combinavam de jeito nenhum [...] Shindo Renmei... O que comandava era um ou dois, como esse que trabalhava em casa, fazia tudo para ganhar dinheiro, não tinha coração. [...] Isso é uma coisa, eu sempre falo, aquilo foi um truque para aproveitar do japonês fanático, ele [o empregado do pai] aproveitava, pegava tudo e ficava mais fanático ainda, não é?"

[O empregado japonês que seu pai tinha] ganhou tanto dinheiro, que todo mundo vendia as terras, naquele tempo, porque ele falava que ia levar para o Japão. Então, vendia o terreno e dava tudo [o dinheiro] para eles. [...] Ele falava que daqui a dois meses ia pro Japão, daqui um mês ia pro Japão..." (Entrevistado S.)

É interessante anotar que nos relatos de pessoas que acompanharam de perto os trágicos acontecimentos, quase não se menciona que as famílias se colocavam em grupos opostos, isto é, que a colônia se cindiu; a imagem que procuram preservar, hoje, parece-nos, é a da colônia unida. A Shindo Renmei aparece como um grupo à parte; entretanto, a análise dos documentos levantados pela polícia paulista na época (inquérito do DEOPS) permite verificar que foram muitos os envolvidos, mesmo em São Paulo. (Dezem, 2000; Morais, 2001)

A cisão apareceu quando foram mencionados fatos concretos, que prejudicaram economicamente alguns derrotistas. Foi o caso de uma entrevistada, na época dona de uma famosa escola japonesa de São Paulo, onde estudavam moças vindas de muitas regiões. Com a divisão entre os vitoristas e os derrotistas, além de ser ameaçada, ela perdeu metade das alunas, pois os seus pais diziam que ela era uma traidora, pois o Japão não havia perdido a guerra; colocaram as filhas em outra escola.

Ao tirarem suas filhas da escola, segundo dona Akama, os pais "colocavam[-nas] na escola que dizia que o Japão tinha ganho [...], na 
Escola Nippak na Castro Alves" (também uma escola feminina). (Entrevistada A).

A Escola Nippak, que teria absorvido alunas da escola de dona Akama, também foi citada por outro entrevistado, morador de Itaquera. Como se pode constatar, o pós-guerra interferiu mais no funcionamento de algumas escolas do que as restrições do Estado brasileiro.

Este fato relatado pela entrevistada Akama sobre o rompimento das famílias com sua escola e o deslocamento das alunas para outra, nos leva a pensar também nos rompimentos dos laços de amizade entre as alunas, entre alunas e professores, isto é, nos afetos que foram profundamente envolvidos e manipulados nesse período. Essa é uma questão que seria interessante analisar em outros estudos.

Os outros entrevistados não falam, como ela, desta cisão das famílias. Concordamos com Dezem (2001), que ao pesquisar recentemente os prontuários dos envolvidos no movimento Shindo Renmei, teve contato com vários descendentes de japoneses envolvidos direta ou indiretamente com este caso e constatou:

"Na ocasião percebi, na maioria, a manifestação de um sentimento em prol da 'administração do esquecimento', envolto de preconceito e configurando um tabu em relação ao assunto. Essa sensação só se tornou perceptível considerando-se a minha familiaridade com o mundo dos prontuários. Hoje podemos considerar que essa questão não foi totalmente superada pela colônia japonesa e que a historiografia tem ainda um compromisso com a memória nacional." (Idem, p. 27)

Também interessante e complementar para o entendimento dos relatos anteriores é a interpretação que alguns dão à derrota do Japão; apesar de todos os sofrimentos durante e no pós-guerra, tanto no Japão como em São Paulo, procuram evidenciar os aspectos positivos da derrota. Um dos entrevistados acha que começaram a viver melhor:

"Quer dizer que... depois da Segunda Guerra, aí mudou tudo. Quer dizer que ficou mais ampla [as relações com as outras pessoas]. Sabe uma coisa, que o japonês geralmente eles estavam conservando? Eles queriam ganhar dinheiro para ir para o Japão. O meu pai também. Ele não queria gastar. [...] 
Depois da guerra sim, aí já perdemos aquela ambição de ir para o Japão. Esquecer o Japão e ficar aqui. Então, quer dizer que mudou tudo. Mudou tudo. [...] Aí que melhorou a vida do japonês. Começou a viver melhor...” (Entrevistado S.) Também alguns vêem aspectos positivos para o Japão:

"A guerra uma parte foi ruim, mas outra parte foi bom [...] Mas, sabe, que eu sempre falo, que seria até ... um exemplo muito bom, a guerra. Ela melhorou bem o Japão, porque se por acaso o Japão tivesse ganhando, ele não ia progredir. [...] Então perdeu, então teve que... Reagiram, não é? Bastante. A indústria japonesa, com a guerra, quer dizer que renovaram tudo. O japonês depois da guerra, a maioria foi arrasada, então puseram máquina nova, isso que foi a sorte do Japão." (Idem)

Tais falas nos remetem aos valores tradicionais da cultura japonesa, especialmente ao gambare (que significa suportar resignadamente todas as adversidades impostas), que é forte mesmo nas gerações mais novas, impulsionando-os para uma vida melhor, na luta contra as adversidades. E a vida melhor em São Paulo, para eles, envolve o respeito mútuo, a solidariedade e a união do grupo. Remetem ainda à questão identitária, à manutenção da cultura e dos valores tradicionais, tão importantes para este grupo.

A análise dos relatos que aqui discutimos, e que são fragmentos sobre um tema ainda pouco analisado a partir dessa fonte, é, portanto, o que conseguimos desvendar sobre os mesmos, e não necessariamente todos os significados que os mesmos carregam. Lembramos entretanto, conforme já ressaltou Schwarzstein (2001), que "la recuperación de la memoria de situaciones extremas plantea al historiador desafios particulares, cuya resolución exige una alta dosis de imaginación" (grifo nosso). Lembramos ainda, Ferrarotti (1984, p. 30), de que "em todo fragmento há a nostalgia da totalidade".

Acreditamos que há muito ainda a ser pesquisado sobre as vivências do grupo japonês durante a Segunda Guerra Mundial e especialmente durante o conflituoso pós-guerra em São Paulo para melhor compreender o processo de recuperação de memórias de situações difíceis e especialmente desse grupo. 
Nosso intuito, nessas poucas páginas, foi menos o de tentar explicar o que ocorreu no período, obter informações sobre os acontecimentos, que algumas obras sobre o tema produzidas nos últimos anos, como a de Dezem (2001) e a mais divulgada Corações sujos, de Fernando Morais (2001) já rastrearam em grande parte, mas procurar entender as representações e interpretações contidas nos relatos orais dos que vivenciaram tais acontecimentos, a partir de questões que inquietam os historiadores orais, como os silêncios, conflitos e incoerências presentes nas memórias. Concordamos com Thompson (1998) quando afirma:

"Si la historia no sólo se ocupa de averiguar acerca del pasado, sino que también trata la importancia del pasado en el presente, entonces la historia oral proporciona una llave com la cual podemos abrir y desentrañar esa relación. Es una herramienta poderosa para descubrir, explorar y evaluar la naturaleza del proceso de memoria histórica, cómo las personas comprenden su pasado, cómo conectan experiencias indivviduales y sus contextos sociales y cómo el pasado se transforma en parte del presente, y cómo las personas lo utilizan para interpretar sus vidas y el mundo que los rodea." (Thompsom, 1998, p. 29)

\section{Referências bibliográficas}

ÁLBUM Comemorativo do $50^{\circ}$ Aniversário do Instituto Educacional "Dona Michie Akama" (Colégio Pioneiro). São Paulo, 1985.

COMISSÃO DE RECENSEAMENTO da Colônia Japonesa de São Paulo. The Japanese Immigrant in Brazil. Tokyo: The University of Tokyo Press, 1994.

DEMARTINI, Zeila de Brito Fabri. Histórias de vida na abordagem de problemas educacionais. Anexo: Depoimentos. In: SIMSON, Olga R. de Moraes von (Org.). Experimentos com histórias de vida: Itália-Brasil. São Paulo: Vértice, 1988. p. 44-71.

- Relatos orais de famílias de imigrantes japoneses: elementos para a história da educação brasileira. Educação \& Sociedade, Revista Quadrimensal de Ciência da Educação, Campinas, v. 21, n. 72, p. 43-72, ago. 2000.

DEMARTINI, Z.B.F.; ESPÓSITO, Y.L. São Paulo no início do século e suas escolas diferenciadas. Ciência e Cultura, São Paulo, v. 41, n. 10, p. 981-995, out. 1989. 
DEMARTINI, Zeila de Brito Fabri et al. Viagens vividas, viagens sonhadas: os japoneses em São Paulo na primeira metade deste século. In: LANG, Alice Beatriz da S. G. (Org.). Família em São Paulo: vivências na diferença. São Paulo: CERU/Humanitas, 1997. (Coleção Textos, série 2, n. 7). p. 77-95.

DEZEM, Rogério. Inventário DEOPS, módulo 3 - japoneses: Shindô Renmei, terrorismo e repressão. São Paulo: Arquivo do Estado/Imprensa Oficial, 2000.

FERRAROTI, Franco. "Entretien avec ... Franco Ferraroti". s. I., 1984. p. 25-51. (sem título da obra)

HANDA, Tomoo. O imigrante japonês: histórias de vida no Brasil. São Paulo: T.A. Queiroz/Centro de Estudos Nipo-Brasileiros, 1987.

HASTINGS, Donald. Japanese Emigration and Assimilation in Brazil. International Migration Review, v. 3, n. 2, 1969.

MAEYAMA, Takashi. Ancestor, Emperor, and Immigrant: Religion and Group Identification of the Japonese in Rural Brazil (1908-1950). Journal of InterAmerican Studies and World Affairs, v. 14, n. 2, 1972.

MARTINS, José de Souza. A chegada do estranho. São Paulo: Hucitec, 1993.

MORAIS, Fernando. Corações sujos: a história da Shindo Renmei. 2a ed. São Paulo: Companhia das Letras, 2001.

QUEIROZ, Maria Isaura Pereira de. Variações sobre a técnica de gravador no registro da informação viva. 2.ed. São Paulo: T.A. Queiroz, 1991. (Biblioteca Básica d Ciências Socias, série 2. Textos; 7).

SAITO, Hiroshi. A presença japonesa no Brasil. São Paulo: Edusp, 1980.

SAYAD, Abdelmalek. L'immigration ou les paradoxes de l'alterité. Paris: Editions Universitaires, 1991.

SCHORSKE, Carl E. Pierre Bourdieu face au problème de l'autonomie. Critique, n. 579-580, p. 697-703, août/sep. 1995.

SCHWARZSTEIN, Dora. História oral, memória e histórias traumáticas. História Oral, São Paulo, n. 4, p. 73-83, jun. 2001.

SEYFERTH, Giralda. Assimilação dos imigrantes no Brasil: inconstâncias de um conceito problemático. In: ENCONTRO ANUAL DA ANPOCS, 24, Caxambu, 2000. mimeo

- Estudo sobre reelaboração e segmentação da identidade étnica. Cadernos CERU, São Paulo, s. 2, n. 13, p. 9-36, 2002.

SHIBATA, Hiromi. As escolas japonesas paulistas (1915-1945): a afirmação de uma identidade étnica. 1997. Dissertação (Mestrado) - Faculdade de Educação, Universidade de São Paulo, São Paulo.

THOMPSON, Paul. A transmissão cultural entre gerações dentro das famílias: uma abordagem centrada em histórias de vida. Ciências Sociais Hoje, São Paulo, p. 29, 1998. 
UMA EPOPÉIA moderna: 80 anos da imigração japonesa no Brasil. São PauIo: Hucitec/Sociedade Brasileira de Cultura Japonesa, 1992.

VELHO, Gilberto. Subjetividade e sociedade: uma experiência de gerações. $2^{a}$ ed. Rio de Janeiro: Zahar, 1989.

Resumo: Abordamos neste artigo as vivências e dilemas enfrentados pelos imigrantes japoneses. Baseamos nossas reflexões em estudos que realizamos com famílias de imigrantes japoneses nos quais entrevistamos homens e mulheres de diferentes gerações. Os relatos orais de diferentes entrevistados permitem observar os seguintes pontos: 1) as vivências diferenciadas entre os que residiam no interior e na capital; 2) as fortes vinculações com o país de origem, o sonho do retorno e o reforço de práticas culturais voltadas para o culto ao imperador; 3) o fortalecimento da Shindo Renmei, a divisão da colônia e o acirramento do preconceito em São Paulo contra os japoneses; 4) a chegada da $2^{a}$ imigração como decorrência da miséria no Japão no pós-guerra e sua inserção junto às famílias mais antigas; 5) as alterações no modo de viver das famílias com o rompimento do "sonho de retorno".

Palavras-chave: japoneses em São Paulo; relatos orais; Segunda Guerra Mundial.

War Marks in Distant Land: the Japanese in São Paulo (Brazil)

Abstract: We approach in the article the living experiences and doubts faced by the Japanese immigrants. We have based our contemplations in studies that we carry through with Japanese immigrants families. The oral reports from different interviewers allowed us to observe the following points: 1) the different living experiences between the country and the capital inhabitants; 2) strong entailing with the country of birth, the turn back dream and the reinforcement on cultural practical directed to Japanese Emperor cult; 3) the postwar period, the strength of Shindo Renmei movement, the colony division and the strong preconception in São Paulo against the Japanese; 4) the arrival of the $2^{\text {nd }}$ immigration as result of the misery in Japan on the postwar period; 5) the family way of life modifications in different fields with the disruption of the turn back dream.

Keywords: Japanese in São Paulo; oral reports; World War II. 